\title{
The effect of ERP on firm performance through information quality and supply chain integration in Covid-19 era
}

\author{
Pirmanta $^{a}$, Zeplin Jiwa Husada Tarigan ${ }^{b^{*}}$ and Sautma Ronni Basana ${ }^{b}$
}

a'Universitas Tama Jaga Karsa, Jl. TB Simatupang No.152, Tj. Bar., Kec. Jagakarsa, DKI Jakarta 12530, Indonesia ${ }^{b}$ Faculty of Business and Economics, Petra Christian University, Jl. Siwalankerto 121-131, Surabaya 60236, Indonesia

\section{H R O N I C L E}

Article history:

Received January 2, 2021

Received in revised format

January, 25, 2021

Accepted May 112021

Available online

May 112021

Keywords:

ERP sustainability

Supply chain integration

Information quality

Firm performance

\section{A B S T R A C T}

\begin{abstract}
The disruption caused by the COVID-19 pandemic has an imbalance between demand and supply in Indonesia's manufacturing industry. The products needed to handle the spread of the virus are in high order, and there is even a product shortage. Products that are not required to prevent a pandemic have stagnated so that the manufacturing industry suddenly reduces capacity. Manufacturing companies need to coordinate quickly to be able to adjust the disruption. Manufacturing companies already have an integrated information technology system that has been the primary process in Enterprise Resources Planning (ERP). Manufacturing companies make ERP their primary system, so they need to be updated and adjusted as needed. This study obtains a questionnaire from Indonesia's manufacturing industry using the google form link and distributed through social media WhatsApp, Facebook and Instagram. Data processing was carried out by using the partial least square of 285 manufacturing company respondents. The results showed that ERP sustainability was able to influence supply chain integration (internal and external). External integration has an impact on information quality, while internal integration does not affect. Supply chain integration and information quality affect increasing firm performance. Research makes a practical contribution to the industry in optimizing ERP systems in Pandemic conditions and a theoretical contribution to ERP sustainability as a mainstay in supply chain integration.
\end{abstract}

\section{Introduction}

The global market has undergone drastic changes after COVID 19. The changes that occur result in restrictions on transportation and goods between countries within a regional area. Restrictions on people's movement, goods and vehicles are also carried out between regions within a country. Many countries have implemented lockdowns to limit people's campaign and goods movement between one nation and another. Under normal conditions, it is stated that globalisation provides competition between companies that are not only in one location, one region or even one country; however, the battle that occurs between companies of different countries is also possible. Companies always build networks with other companies to collaborate to produce something that can be mutually beneficial. The conditions for COVID 19 that occur are very different due to the many policies carried out by the state to limit the arrival of goods from certain countries, except for something needed by the government, drugs and materials used to reduce the spread of COVID are required (Govindan et al., 2020). This change in order has resulted in the industry having to make changes internally. The company tries to pay attention to its speed and agility. Internal changes should be able to anticipate changes that occur external to the company. Industry-built skill will result in good flexibility. Companies should involve their suppliers to be able to provide raw materials quickly according to customer requests. The condition of COVID resulted in a decrease in demand from customers

* Corresponding author

E-mail address: zeplin@petra.ac.id (Z. J.H. Tarigan)

C 2021 by the authors; licensee Growing Science. doi: $10.5267 /$ j.uscm.2021.5.004 
for most manufactured products, except for products used to anticipate the spread of COVID. Manufacturing companies integrate with external companies and optimise internal company integration to respond to the disruption that occurs. The company builds the ability to manage intra-organization and extra organisation with supply chain integration (Cheng et al. 2016; Subburaj et al., 2019). Internal integration makes it easy for managers to communicate quickly and remove obstacles in the company's organisational structure (Sacristán-Díaz et al., 2018).

Internal integration is cross-functional integration or a relationship between organisational structures (Liu and Lee, 2018. The form of relationship that occurs is the coordination of activities from different business functions to work together effectively and efficiently to achieve company goals (Huo et al., 2014). Cross-functional integration is not limited to integrating business functions within the company and includes integration with other companies that are members of the supply chain. The supply chain is a company's strategy to connect internal activities and external to improve company performance (Khanuja \& Jain, 2019). Cross-functional integration between companies in the supply chain can increase the productivity of the entire supply chain. Cross-functional integration positively impacts companies in accessing fast data and real-time integration, making it easier for leaders to make appropriate decisions. The company's internal integration has gone well through the implementation of enterprise resources planning (ERP). The company's supply chain integration can rely on an ERP system that is updated and as needed. Supply chain integration can provide fast information to all parties, both internal and external, to the company. The information that is provided can be used to make the right decisions to improve operational performance. Supply chain integration allows companies to collaborate with external parties to enhance their capabilities (Liu et al., 2016). The integration that occurs provides fast information, synchronises company planning with partners, resolves problems, and builds competitive strategies in the supply chain flow. Supply chain integration consists of external Integration and internal Integration (Sundram et al., 2018). Supply chain external integration consists of supplier integration and customer integration, and internal supply chain integration is determined (Spiegel et al., 2014; Sacristán-Díaz et al., 2018). Companies need to capture demand well according to customers' requirements (Ayoub et al., 2017). Integrated information technology used to coordinate and communicate effectively with corporate partners. The use of information technology provides on-time interaction and builds robust integrations. Information technology tools make both parties' data integrated and create high flexibility because they collaborate in establishing joint plans, develop products jointly with customers, determine forecasting together and reduce inventory levels. External integration with suppliers aims to involve suppliers in knowing the material and supporting material needs for the company quickly (Huo, 2012). Suppliers are given access to the company's information technology system to detail the company's needs. Integration built with external parties must be supported by internal Integration (Liu \& Lee, 2018). Supply chain internal integration is a synchronisation process between all organisation functions in achieving the stated goals (Flynn et al., 2010). Internal company integration focuses on meeting customer demands and providing products according to specified requirements (Ayoub et al., 2017). Internal Integration coordinates and communicates between functions within the organisation in making products with the availability of raw materials provided by suppliers.

Implementing external and internal integration of companies requires integrated information technology to increase fast communication in the company in enterprise resource planning (ERP). Integrated information systems (ERP) enable companies to make the right decisions (Ince et al., 2013). ERP can provide an overall picture of the company to be suitable for external changes (Su and Yang, 2010). ERP is equipped with computer hardware and software to manage its money resources (Siagian and Tarigan, 2020b). ERP can coordinate and integrate data in each area of the business process. ERP integration produces fast decision-making, quick financial reports, sales on-time reports, production reports, and inventory reports. ERP enables part or all of its functions to be automated and integrated with software modules in small and medium enterprises (Sharma and Daniel, 2016). ERP is determined with updated compatibility technology to keep up with changes. According to company needs, software and hardware upgrades are called ERP sustainability (Tarigan et al., 2019). Companies' ERP can provide information quality and information sharing (Adaileh \& Abu-alganam, 2010). Internal integration in companies through data integration between real-time functions can provide Information Quality (Zhou et al. 2014). Information quality that occurs provides conditions for building customer integration and impacting its operational performance (Chavez et al., 2015). Built-in integration allows related functions to get data in real-time. Internal integration enables functions to quickly understand internal conditions, making it easier to coordinate and integrate with supplier partners and customers. Internal company integration can increase financial performance in manufacturing companies (Qi et al., 2017). Internal company integration and external integration impact firm performance on fast-moving consumer goods (Siagian et al. 2020a). The company's ability to coordinate and coordinate quickly by integrating internal integration can improve company performance (Sundram et al., 2018; Huo, 2012; Yuen \& Thai, 2017). Companies' power to build external integration by communicating and collaborating can improve operational performance (Sundram et al., 2018; Cheng et al. 2016, Huo, 2012; Tarigan \& Hotlan, 2021). Previous research still carried out partial testing of the two concept variables, and it was still limited to normal conditions without era disruption. This research was conducted on five variables of ERP sustainability, supply chain internal integration, supply chain external integration, information quality and operational performance simultaneously in manufacturing companies in the disruption of the COVID 19 era. The role of ERP sustainability is significant in building intra-organizational and inter-organisational integration to generate quality information for decision-makers to improve operational performance. This study provides managers with practical contributions to creating effective and efficient communication and coordination for internal and external companies, 
theoretical contribution to the importance of ERP implementation in building supply chain integration to improve business performance.

\section{Literature Review}

\subsection{Relationship between the concept of ERP Sustainability and supply chain integration}

ERP is an information system capable of integrating intra-organizational and inter-organisational using a single database. ERP upgrades are a way for companies to maintain ERP performance and sustainability to produce information quality (Tarigan et al., 2019). ERP in companies can impact operational process integration, customer and relationship integration, planning and control process integration in Taiwan companies (Su and Yang, 2010). ERP System is declared successful if it can increase efficiency and effectiveness for the company. ERP systems can improve internal supply chain integration and provide external supply chain integration (Adaileh and Abu-alganam, 2010). ERP system is a software package that can integrate business processes and company business functions. ERP systems related to information quality and organisation impact can determine strategic partnerships with suppliers and customer relationships (Ince et al., 2013). ERP systems built by manufacturing companies affect supply chain integration to improve supply chain performance (Tarigan et al., 2019; Siagian \& Tarigan, 2020b).

\section{$\mathbf{H}_{1}$ : ERP Sustainability influences supply chain internal integration. \\ $\mathbf{H}_{2}$ : ERP Sustainability influences supply chain external integration.}

\subsection{Relationship between supply chain internal integration concept and supply chain external integration}

Supply chain internal integration can make data integration between functions within the company on time (Flynn et al., 2010). Internal integration shows a company's ability to build collaboration and cooperation between parts to meet demand (Ayoub et al., 2017). The data contained in the marketing department about product demand is automatically integrated with the production and purchasing department (Tarigan and Hotlan, 2021). The ERP system in the company provides and automatically calculates the need for work time in production and the need for raw materials in the purchasing department when inventory is not available. Internal integration is the basis for companies in determining external Integration (Sacristán-Díaz et al., 2018; Spiegel et al., 2014; Yuen and Thai, 2017). Internal integration in companies can have an impact on external Integration (Cheng et al. 2016). Internal integration can form a planning system and coordination that occurs internally in service companies, impacting customer integration as part of external Integration (Liu and Lee, 2018). Internal integration and process integration affect product provisioning by customer orders at manufacturing companies with 100 employees or more in China (Huo et al., 2014). Internal integration can positively impact customer integration and supplier integration (external integration) in 617 manufacturing companies in China (Huo, 2012). Internal integration in China's manufacturing companies can not impact increasing external Integration (Qi et al., 2017).

\section{H3: Supply chain internal integration influences supply chain external integration.}

\subsection{Relationship between the concept of supply chain integration to information quality}

Supply chain integration is the company's ability to collaborate with internal and external companies in achieving fast, efficient, and effective processes in the physical flow of goods, accurate information flow and financial flow (Subburaj et al., 2019). The integrated supply chain that is built accelerates the company to interact and communicate between the company's internal and external functions and impact information sharing and information quality (Li \& Lin, 2006). This integration also provides internal data for all processes. The data on the internal organisation can be integrated with a partner, likely customers and suppliers. Internal integration and external integration related to organisation and technology can impact information quality (Gustavsson, 2007). The integration formed by all the existing components is highly dependent on fast, high and quality information exchange. Information quality in the company's supply chain integration is the main requirement to communicate well with all parties (Zhou et al., 2014). Information sharing and information quality improve effective and efficient communication between intra-organizational and inter-organisational functions (Lusiantoro et al., 2018). Customer integration impacts information quality and fully mediates operational performance in manufacturing companies in the Republic of Ireland (Chavez et al., 2015). Supply chain integration has a significant impact on information quality in providing quality products along the supply chain flow (Tarigan et al., 2021).

H4: Supply Chain Internal Integration has an impact on information quality.

H5: Supply Chain External Integration has an impact on information quality.

\subsection{The relationship between the concept of supply chain internal integration to the operational performance}

Supply chain internal integration by coordinating and communicating quickly and efficiently impacts company performance (Sundram et al., 2018; Yuen \& Thai, 2017). Supply chain internal integration does not have a direct impact on performance (Cheng et al., 2016). Internal integration in companies with more than 100 employees in China shows that data integration 
between functions and inventory integration can impact operational performance (Huo et al., 2014). The 3 PL (third-party logistics providers) obtained by 161 in Taiwan show that the internal integration formed by placing personnel between functional departments and integration between departments does not affect the service performance in creating customer satisfaction and on-time delivery (Liu \& Lee, 2018). Supply chain internal integration which is part of supply chain integration has an impact on operational performance (Tarigan et al., 2021; Subburaj et al., 2019). Integrated internal systems in fast-moving consumer goods involve improving company performance (Siagian, et al. 2020a). Supply chain internal integration can impact operational performance in 617 manufacturing companies (Huo, 2012; Khanuja \& Jain, 2019). Internal integration can increase manufacturing's financial performance (Qi et al., 2017; Baheshti et al., 2014). Based on this relationship, a research hypothesis is established:

\section{H6: Supply chain internal integration has an impact on operational performance.}

\subsection{Relationship between supply chain concepts external integration on operational performance}

company partners with its suppliers and suppliers to make the company more flexible and deal with sudden changes. Companies can build external integration to improve operational performance (Sundram et al., 2018; Yuen \& Thai, 2017). External integration in fast-moving consumer goods impacts improving company performance (Siagian, et al. 2020a). Cheng et al. (2016) stated that supply chain external integration directly affects operational performance. Customer integration and supplier integration, which is combined, is called external integration, increasing firm performance in 617 manufacturing companies in China (Huo, 2012). Supply chain external integration which is part of supply chain integration has an impact on operational performance in manufacturing industry (Tarigan et al., 2021; Subburaj et al., 2019). Customer integration is part of external integration that impacts improving service performance in 3 PL companies (third-party logistics providers) in Taiwan (Liu \& Lee, 2018). External integration in the manufacturing companies in China has no impact on financial performance (Qi et al., 2017). External integration influences financial performance in Swedish Manufacturing (Baheshti et al., 2014).

\section{H7: Supply chain external integration influences operational performance.}

\subsection{Relationship between the concept of information quality and operational performance}

Quality of data that the company has is formed in the ERP system. Departments related to entering data into the ERP system are in accordance with the real data so that the data shows the actual situation that is ongoing in company operations. Information quality provides effectiveness in the supply chain to improve overall company performance (Zhou et al., 2014). Information quality in building partnerships with external parties increases company capacity and effectiveness to improve performance and competitiveness (Tarigan and Hotlan, 2021). Information quality obtained provides accurate inventory level information and proper planning to provide company performance (Lusiantoro et al., 2018). Information quality can improve operational performance in manufacturing companies in the Republic of Ireland (Chavez et al., 2015).

\section{Hs: Information quality influences the operational performance.}

\section{Research Methods}

In this study, samples are manufacturing companies located in Indonesia, especially in big cities including Jakarta, Surabaya, Medan, Makassar, Semarang, Samarinda, Malang, Solo, Manado Bali and others. Sampling research is a manufacturing company that implements information technology that is integrated between internal functions. Information technology that is owned in the form of ERP can be combined with corporate partners. The questionnaire is in the form of a google form link which is distributed to respondents. Researchers used seventy field enumerators to send links to respondents to fill in using the Whatsapp, Facebook, and Instagram communities. The questionnaire link is estimated to be sent to more than 1000 respondents who have worked in manufacturing companies. It is found that the number of respondents who gave responses in filling out the questionnaire was 465 respondents. Initial checking on the questionnaire filling found that the supervisor level up as the ERP key user and the decision-maker at the company middle manager level totalled 292 respondents. Seven respondents did not complete the filling. The data used to analyse processed further to answer the entire research hypothesis is 285 and uses partial least square (PLS) analysis (Khan et al., 2019). The measurement items used to measure ERP sustainability are data integration, System ERP stability, software upgrades, hardware upgrade and technology utilisation. (Tarigan et al., 2019; Siagian and Tarigan, 2020b). Measurement items used to measure supply chain internal integration with inventory data integration, data integration with cross-function, real-time integration, process improvement with cross-functional (Qi et al., 2017; Baheshti et al., 2014; Ayoub et al., 2017; Hani, 2020). Measurement items used to measure supply chain external integration by sharing information with partners, improving processes with partners, long-term relationships with partners, joint decision making with partners, synchronising planning with partners (Qi et al., 2017; Cheng et al., 2016; Liu et al., 2016; Huo et al., 2014). The measurement items used to measure information quality are accuracy data, reliable data, data relevance, easily accessible data, and data timeliness (Lusiantoro et al., 2018; Tarigan et al., 2019). Firm performance variables are measured by product quality, delivery 
flexibility, order fulfilment, and customer satisfaction (Cheng et al., 2016; Sundram et al., 2018; Huo et al., 2014; Siagian et al., 2020a; Tarigan \& Hotlan, 2021).

\section{Result}

Characteristics of the respondents in this study have based the position with the top management level and company owners amounting to $142(50 \%)$, Manager $120(42 \%)$ and supervisor $23(8 \%)$. Characteristics the respondents, based on the number of workers in the manufacturing company, the number is less than 20 employees of 140 manufacturing companies (49\%), the number of employees between 20 employees and 50 employees of 45 manufacturing companies (16\%), the number of employees between 50 employees to 100 employees of 25 manufacturing companies (9\%) and more than 100 employees with a total of 75 manufacturing companies $(26 \%)$. Data processing with PLS obtained validity and reliability values shown in Table 1.

\section{Table 1}

Validity and Reliability for Measurement Model

\begin{tabular}{|c|c|c|c|}
\hline Item & Loading Factor & Composite Reliability & Average variance extracted (AVE) \\
\hline ERP Sustainability & & \multirow{6}{*}{0.85} & \multirow[t]{6}{*}{ 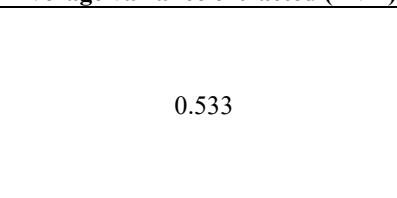 } \\
\hline Data integration & 0.706 & & \\
\hline System ERP stability & 0.642 & & \\
\hline Software upgrade & 0.76 & & \\
\hline Hardware upgrade & 0.743 & & \\
\hline Technology utilisation & 0.79 & & \\
\hline \multicolumn{2}{|l|}{ Supply chain internal integration } & \multirow{5}{*}{0.792} & \multirow{5}{*}{0.59} \\
\hline Inventory data integration & 0.758 & & \\
\hline Data integration with cross-function & 0.739 & & \\
\hline Real-time integration cross-function & 0.729 & & \\
\hline Process improvement cross-functional & 0.555 & & \\
\hline \multicolumn{2}{|l|}{ Supply chain External Integration } & \multirow{6}{*}{0.848} & \multirow{6}{*}{0.531} \\
\hline Sharing information with partner & 0.736 & & \\
\hline Improving process with partner & 0.637 & & \\
\hline Long term relationship with the partner & 0.826 & & \\
\hline Joint decision making with partner, & 0.616 & & \\
\hline Planning synchronisation with partners & 0.804 & & \\
\hline \multicolumn{2}{|l|}{ Information quality } & \multirow{6}{*}{0.769} & \multirow{6}{*}{0.512} \\
\hline Accuracy data & 0.512 & & \\
\hline Reliable data & 0.57 & & \\
\hline Relevance data & 0.79 & & \\
\hline Easily accessible data & 0.749 & & \\
\hline Timeliness of data & 0.636 & & \\
\hline \multicolumn{2}{|l|}{ Firm Performance } & \multirow{5}{*}{0.839} & \multirow{5}{*}{0.567} \\
\hline Quality product & 0.785 & & \\
\hline Delivery flexibility & 0.666 & & \\
\hline Order fulfilment & 0.709 & & \\
\hline Customer satisfaction & 0.84 & & \\
\hline
\end{tabular}

Based on Table 1, it is found that the loading factor value is above 0.500 and composite reliability is above 0.700 , and the AVE value has been above 0.500 so that the research model has met goodness of fit requirements.

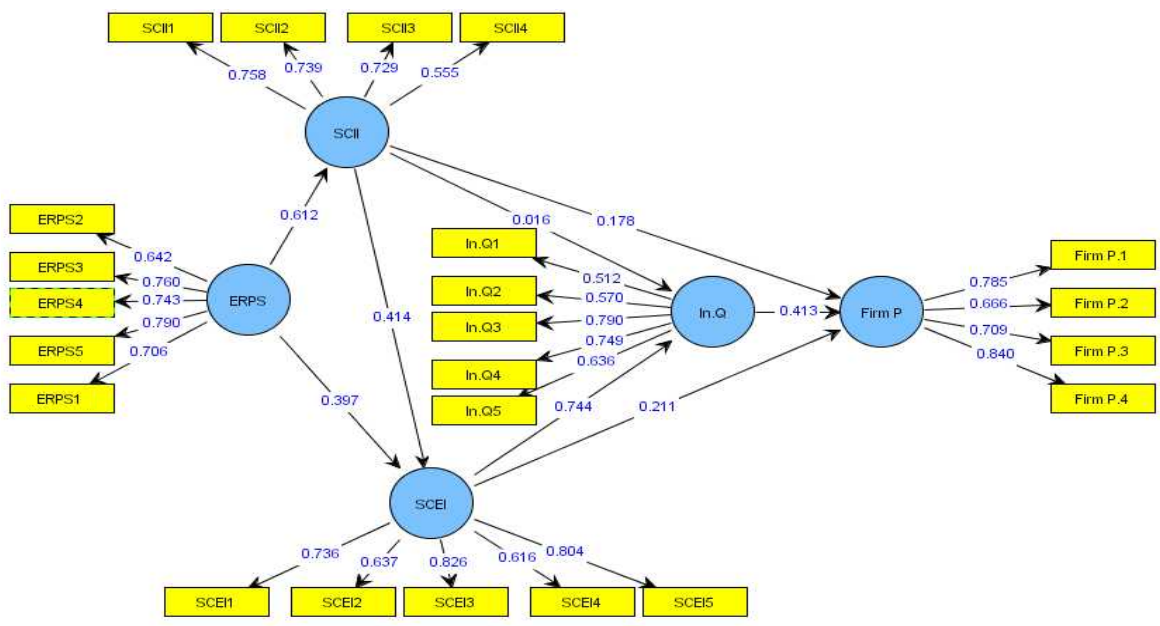

Fig. 1. Path Analysis for research models 
Table 2

Path coefficient for direct effect

\begin{tabular}{cccc}
\hline Direct Effect & Original sample estimate & Mean of sub samples & Standard Deviation \\
\hline ERPs $\rightarrow$ SCII & 0.612 & 0.617 & 0.042 \\
Erps $\rightarrow$ SCEI & 0.649 & 0.657 & 0.049 \\
SCII $\rightarrow$ In. Q & 0.020 & 0.030 & 0.068 \\
SCEI $\rightarrow$ In. Q & 0.743 & 0.740 & 0.050 \\
SCII $\rightarrow$ Firm P & 0.178 & 0.176 & 0.074 \\
SCEI $\rightarrow$ Firm P & 0.217 & 0.219 & 0.297 \\
In.Q $\rightarrow$ Firm P & 0.409 & 0.410 & 0.100 \\
\end{tabular}

Results of path analysis in Fig. 1 and Path coefficient showed Table 2, a direct effect of the research hypotheses. The total number of hypotheses in the study was eight, with seven hypotheses declared acceptable because the t-statistic value was above 1.96. One hypothesis this study was rejected with the t-statistical value of 0.297 . The results of path analysis are shown in Fig. 1, and the path coefficient in Table 2. The seven accepted hypotheses are: first, ERP Sustainability affects supply chain internal integration $\left(\mathrm{H}_{1}\right.$ supported). Second, ERP Sustainability influences supply chain external integration $\left(\mathrm{H}_{2}\right.$ supported). Third, Supply chain internal integration affects supply chain external integration ( $\mathrm{H}_{3}$ supported). Fourth, supply chain external integration has an impact on information quality $\left(\mathrm{H}_{5}\right.$ supported). Fifth, Supply chain internal integration has an effect on operational performance $\left(\mathrm{H}_{6}\right.$ as supported). Sixth, supply chain external integration impacts operations performance $\left(\mathrm{H}_{7}\right.$ supported) and last, information quality affects operational performance ( $\mathrm{H}_{8}$ supported). A hypothesis that is rejected is that supply chain internal integration impacts information quality $\left(\mathrm{H}_{4}\right.$ is not accepted).

\section{Discussion}

This research has an essential contribution to companies in overcoming the disruption caused by COVID 19 to maintain a balance between demand and supply. Companies need real-time information from the company's internal conditions so that it is easy to adjust to the company's external conditions. The manufacturing industry in Indonesia already has an integrated information technology system in the form of ERP. The company has maintained its ERP system as a company's operating system continuously and is updated continually. ERP sustainability can integrate internal company departments in a database. ERP Sustainability influences supply chain internal integration. ERP software and hardware used are always being updated, and the technology utilisation can integrate inventory data across organisational functions for use. The integration between functions runs in real-time so that the supply chain internal integration runs well. ERP Sustainability influences supply chain external integration. The role of ERP sustainability in integration with partners. An integrated corporate ERP can provide data in real-time. Companies can build long-term relationships with partners and synchronise planning with partners efficiently and make it possible to share information. This study supports the research results that state that ERP sustainability affects supply chain integration (Tarigan et al., 2019; Su \& Yang, 2010; Adaileh \& Abu-alganam, 2010; Siagian \& Tarigan, 2020b).

Supply chain internal integration provides influence on supply chain external integration Internal integration between functions that are running well, with the integration of inventory data for all departments and real-time data integration can build synchronisation of planning and information sharing according to everyday needs. This study supports the research results that reveal that supply chain internal integration influences supply chain external integration (Cheng et al., 2016; Ayoub et al., 2017; Liu and Lee, 2018; Huo, 2012; Tarigan et al., 2021; Hani,2020)). Supply chain internal integration has no impact on information quality. Internal integration in companies has been able to integrate data in real-time between functions. ERP company things have been going well so far that the quality of the information obtained is always accurate and used collectively to make decisions. The information quality owned by the company is excellent. The supply chain internal integration that the company has built has basic requirements, namely information quality that must be adequately available before using ERP at the initial stage of implementation. This study is different from the research results that state that supply chain internal integration impacts information quality (Li \& Lin, 2006; Gustavsson, 2007) and research supports Zhou et al. (2014). Supply chain external integration has an impact on information quality. The company builds a long-term relationship with partners and synchronises planning with partners consistently and ongoing, providing the right quality information. The company and its partners can share information to enable easy access to partner data relevant to needs. Supply chain external integration makes companies and partners have accurate and reliable data. This research supports the study results on Supply chain external integration, which impacts information quality (Lusiantoro et al., 2018; Chavez et al., 2015; Zhou et al., 2014). Supply chain internal integration has an impact on operational performance. Internal integration of companies in sharing information, Integration of inventory levels and Integration of real-time data determines delivery accuracy and increases customer satisfaction. Data about products ordered by customers can be monitored directly on the company's ERP system so that customers can adjust their length planning. This study supports the research results that states that supply chain internal integration influences operational performance (Sundram et al., 2018; Cheng et al., 2016; Huo et al., 2014; Siagian et al., 2020a; Huo, 2012; Hani, 2020). Supply chain external integration has an impact on operational performance. Integration with existing partners in sharing information with partners, synchronising resource use planning, and long-term relationships with partners is running well. External integration involves customers in the company system to increase customer satisfaction and fulfil quality products according to customer needs. This study supports the research 
results that state that Supply chain external integration influences operational performance (Sundram et al., 2018; Siagian et al., 2020a; Cheng et al., 2016; Huo, 2012, Liu \& Lee, 2018). Information quality influences operational performance. Company information quality is a visible result in the company's ERP system, which allows it to be accessed by all internal parties of the company and company partners. Accurate data and easy access provide conditions for customers to know the time for product delivery to fulfil order fulfilment. Customers also experience increased satisfaction in accessing neededrelevant data. Increased easy access for customers to company ERP allows customers to monitor internal company conditions. This study confirms the research results on Information quality influence operational performance (Zhou et al., 2014; Lusiantoro et al., 2018; Chavez et al., 2015).

\section{Conclusion}

The manufacturing industry underwent sudden changes in the COVID-19 era. Companies experience an imbalance in demand and supply. Products that are needed to prevent the spread of the virus experience a high level of order, and there is even a shortage of products at certain times, while products that are not needed in dealing with viruses do not move. This condition causes the company to reduce production capacity to survive in conditions of disruption. The manufacturing industry has ERP, which has been relied on as the company's single operational system. Based on the discussion results, ERP sustainability, which has been running continuously, has been able to impact supply chain internal integration and allows all industries to integrate with external partners as a form of supply chain external integration. Supply chain internal integration has no direct impact on information quality. Companies implementing ERP are required to have useful information quality. This condition shows that the information quality that the company has internally is adequate. Supply chain integration (internal Integration and external Integration) can increase customer satisfaction and quality products and information on the proper delivery. The resulting supply chain integration and information quality have an impact on increasing firm performance. This study contributes to practitioners continuously updating and maintaining their ERP systems to improve company performance. This study contributes theoretically to the development of the concept of supply chain integration and ERP sustainability.

\section{References}

Adaileh, M.J., \& Abu-alganam, K.M. (2010). The Role of ERP in supply chain integration. International Journal of Computer Science and Network Security, 10(5), 274-279,

Ayoub, H.F., Abdallah, A.B., \& Suifan, T.S. (2017). The effect of supply chain integration on technical innovation in Jordan: The mediating role of knowledge management. Benchmarking: An International Journal, 24(3), 594-616. DOI 10.1108/BIJ-06-2016-0088

Baheshti, H.M., Oghazi, P., Mostaghel, R., \& Hultman, M. (2014). Supply chain integration and firm performance: an empirical study of Swedish manufacturing firms. Competitiveness Review, 24(1), 20-31, doi.org/10.1108/CR-06-20130060

Chavez, R., Yu, W., Gimenez, C., Fynes, B. and Wiengarten, F. (2015). Customer integration and operational performance: the mediating role of information quality. Decision Support Systems, 80, 83-95, doi.org/10.1016/j.dss.2015.10.001

Cheng, Y., Chaudhuri, A. and Farooq, S. (2016). Interplant coordination, supply chain integration, and operational performance of a plant in a manufacturing network: a mediation analysis. Supply Chain Management: An International Journal, 21(5), 550 -568, DOI 10.1108/SCM-10-2015-0391

Flynn, B.B., Huo, B., \& Zhao, X. (2010). The impact of supply chain integration on performance: a contingency and configuration approach. Journal of Operations Management, 28(1), 58-71, doi.org/10.1016/j.jom.2009.06.001

Govindan, K., Mina, H., \& Alavi, B. (2020). A decision support system for demand management in healthcare supply chains considering the epidemic outbreaks: A case study of coronavirus disease 2019 (COVID-19). Transportation Research Part E, 138, 101967, doi.org/10.1016/j.tre.2020.101967

Gustavsson, M. (2008). Information quality implications of planning process integration. Journal of Manufacturing Technology Management, 19(8), 933-952, doi.org/10.1108/17410380810911718

Hani, J.S.B. (2020). The moderating role of lean operations between supply chain integration and operational performance in Saudi manufacturing organizations, Uncertain Supply Chain Management, 9(1), 169-178, DOI: 10.5267/j.uscm.2020.10.004,

Huo, B. (20112). The impact of supply chain integration on company performance: an organisational capability perspective. Supply Chain Management: An International Journal, 17(6), 596-610, doi.org/10.1108/13598541211269210

Huo, B., Qi, Y., Wang, Z. and Zhao, X. (2014). The impact of supply chain integration on firm performance: The moderating role of competitive strategy. Supply Chain Management: An International Journal, 19(4), 369-384, doi.org/10.1108/SCM-03-2013-0096

Ince, H., Imamoglu, S.Z., Keskin, H., Akgund, A., \& Efe, M.N. (2013). The impact of ERP systems and supply chain management practices on firm performance: Case of Turkish companies. Procedia - Social and Behavioral Sciences, 99, 1124 - 1133, doi.org/10.1016/j.sbspro.2013.10.586

Khan, G.F., Sarstedt, M., Shiau, W.-L., Hair, J.F., Ringle, C.M., \& Fritze, M.P. (2019). Methodological research on partial least squares structural equation modeling (PLS-SEM): An analysis based on social network approaches. Internet Research, 29(3), 407-429, doi.org/10.1108/IntR-12-2017-0509 
Khanuja, A., \& Jain, R.K. (2019). Supply chain integration: a review of enablers, dimensions and performance. Benchmarking: An International Journal, 27(1), 264-301, doi.org/10.1108/BIJ-07-2018-0217

Li, S., \& Lin, B. (2006). Accessing information sharing and information quality in supply chain management. Decision Support Systems, 42(3), 1641-1656., doi.org/10.1016/j.dss.2006.02.011

Liu, C.-L., \& Lee, M.-Y. (2018). Integration, supply chain resilience, and service performance in third-party logistics providers. The International Journal of Logistics Management, 29(1), 5-21, doi.org/10.1108/IJLM-11-2016-0283

Liu, H., Wei, S., Ke, W., Wei, K.K., \& Hua, Z. (2016). The configuration between supply chain integration and information technology competency: A resource orchestration perspective. Journal of Operations Management, 44, 13-29, doi.org/10.1016/j.jom.2016.03.009

Lusiantoro, L., Yates, N., Mena, C., \& Varga, L. (2018). A refined framework of information sharing in perishable product supply chains. International Journal of Physical Distribution \& Logistics Management, 48(3), 254-283, doi.org/10.1108/IJPDLM-08-2017-0250

Qi, Y., Huo, B., Wang, Z., \& Yeung, H.Y.J. (2017). The impact of operations and supply chain strategies on integration and performance. International Journal of Production Economics, 185, 162-174, doi.org/10.1016/j.ijpe.2016.12.028

Sacristán-Díaz, M., Garrido-Vega, P., \& Moyano-Fuentes, J. (2018). Mediating and non-linear relationships among supply chain integration dimensions. Distribution \& Logistics Management, 48(7), 698-723, doi.org/10.1108/IJPDLM-062017-0213

Siagian, H., Jade, K., \& Tarigan, Z.J.H. (2020a). The role of affective leadership in improving firm performance through the integrated internal system and external integration FMCG Industry. International Journal of Data and Network Science, 4(4), 365-372, DOI: $10.5267 / \mathrm{j} . \mathrm{ijdns}$.2020.9.002

Siagian, H. \& Tarigan, Z.J.H. (2020b). Why enterprise resources planning technology is needed for logistics integration and retailer satisfaction. International Journal of Innovation, Creativity and Change, 13(11), 1090-1104.

Sharma, S., \& Daniel, E.M. (2016). Isomorphic factors in the adoption of ERP by Indian medium-sized firms. Journal of Enterprise Information Management, 29(6), 798-821, doi.org/10.1108/JEIM-07-2014-0076

Spiegel, T., de Medeiros Vasconcelos, P.E., Lopes Porto, D., \& Caulliraux, H.M. (2014). Supply chain integration research: an overview of the field. International Journal of Supply Chain Management, 3(1), 12-20.

Su, Y. F., \& Yang, C. (2010). A structural equation model for analysing the impact of ERP on SCM. Expert Systems with Applications, 37, 456-469, doi.org/10.1016/j.eswa.2009.05.061

Subburaj, A., Sriram, V.P., \& Mehrolia, S. (2019). Effects of supply chain integration on firm's performance: A study on micro, small and medium enterprises in India. Uncertain Supply Chain Management, 8(1), 231-240, DOI: 10.5267/j.uscm.2019.7.001

Sundram, V.P.K, Bahrin, A.S, Munir, Z.B.A. \& Zolait, A.H. (2018). The effect of supply chain information management and information system infrastructure: The mediating role of supply chain integration towards manufacturing performance in Malaysia. Journal of Enterprise Information Management, 31(5), 751-770, doi.org/10.1108/JEIM-062017-0084

Tarigan, Z.J.H., Mochtar, J., Basana, S.R., \& Siagian, H. (2021). The effect of competency management on organizational performance through supply chain integration and quality. Uncertain Supply Chain Management, 9(2), 283-294, doi: 10.5267/j.uscm.2021.3.004

Tarigan, Z.J.H., Lianto, \& Basana, S.R. (2019). The Impact of Organizational Commitment on Upgrading ERP for Maintaining the Quality of Information. IOP Conf. Series: Materials Science and Engineering, 473, 012051, doi:10.1088/1757-899X/473/1/012051

Tarigan, Z.J.H., \& Siagian, H. (2021). The effects of strategic planning, purchasing strategy and strategic partnership on operational performance. Uncertain Supply Chain Management, 9(2), 283-294, doi: 10.5267/j.uscm.2021.3.004, DOI: 10.5267/j.uscm.2021.2.006

Yuen, K.F., \& Thai, V.V. (2017). The influence of supply chain integration on operational performance: A comparison between product and service supply chains. The International Journal of Logistics Management, 28(2), 444-463, doi.org/10.1108/IJLM-12-2015-0241

Zhao, L., Huo, B., Sun, L., \& Zhao, X. (2013). The impact of supply chain risk on supply chain integration and company performance: a global investigation. Supply Chain Management: An International Journal, 18(2), 115-131, doi.org/10.1108/13598541311318773

Zhou, H., Shou, Y., Zhai, X., Li, L., Wood, C., \& Wu, X. (2014). Supply chain practice and information quality: a supply chain strategy study. International Journal of Production Economics, 147, 624-633, doi.org/10.1016/j.ijpe.2013.08.025

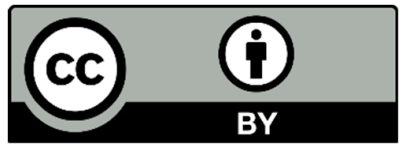

(C) 2021 by the authors; licensee Growing Science, Canada. This is an open access article distributed under the terms and conditions of the Creative Commons Attribution (CC-BY) license (http://creativecommons.org/licenses/by/4.0/). 